\title{
Effect of Baseline Clinical and Laboratory Characteristics of Patients with Type 1 Diabetes Mellitus on Metabolic Control
}

\author{
Tip 1 Diyabetes Mellituslu Hastaların Tanı Anındaki Klinik ve Laboratuvar \\ Özelliklerinin Metabolik Kontrole Etkisi
}

$\underline{\text { Özlem Kara }}^{1}$

${ }^{1}$ Bursa Yüksek İhtisas Eğitim ve Araştırma Hastanesi, Çocuk Endokrinoloji Kliniği, Bursa

\begin{abstract}
Objectives: Type 1 diabetes mellitus (T1DM) is a chronic metabolic disease that is common in childhood. Good metabolic control slows down and even prevents development of diabetes-related micro-vascular complications. Therefore determination of the affecting factors for metabolic control is important. To evaluate effect of at the time of diagnosis demographic, clinical and laboratory characteristics of children and adolescents with T1DM on metabolic control.

Materials and Methods: The metabolic control status was evaluated according to the mean hemoglobin A1c (HbA1c) values of the recent one year as good (HbA1c $<7.5 \%$ ), moderate (HbA1c 7.5-9\%) and poor $(\mathrm{HbA} 1 \mathrm{c}>9 \%)$. The patient data and the mean HbA1c levels were compared.

Results: Data were collected on 144 patients with T1DM. The peak ages at diagnosis were determined to be $4-6$ years $(21.52 \%)$ and $12-14$ years $(20.83 \%)$. The first-degree relatives had the diagnosis of T1DM in $10 \%$ of the patients. The mean HbA1c value was determined as 7.7\% (7.2-8.8) in girls and 7.8\% (7.0-8.6) in boys. Metabolic control was good in $38.19 \%$, moderate in $41.68 \%$ and poor in $20.13 \%$. The mean age at diagnosis was $9.13 \pm 4.30$ years in the patients with good metabolic control and $10.19 \pm 4.26$ years in patients with poor metabolic control $(\mathrm{p}=0.252)$. Metabolic control was found to be better in the patients who had T1DM in the family $(\mathrm{p}=0.002)$.

Conclusion: Metabolic control was found to be good in patients who had DM in the family. It is thought that patients and their families care about diabetes management after diagnosis, regulate their lifestyle according to diabetes. According to the result, increasing the awareness of diabetes in the family and continuing the motivating trainings for the patients will have a positive effect on the management of diabetes.
\end{abstract}

Keywords: Awareness, Childhood, Metabolic control, Type 1 diabetes mellitus

\section{$\ddot{O} z$}

Amaç: Tip 1 diabetes mellitus (T1DM) çocukluk yaş grubunda sık görülen kronik metabolik bir hastalıktır. İyi metabolik kontrol ile diyabetle ilişkili mikrovasküler komplikasyonların ilerlemesi yavaşlar hatta gelişimi önlenebilmektedir. Bu nedenle metabolik kontrolü etkileyen faktörlerin belirlenmesi önemlidir. Bu çalışmada ile tanı anındaki T1DM'li çocuk ve ergenlerin demografik, klinik ve laboratuvar özelliklerinin metabolik kontrol üzerindeki etkisini değerlendirilmesi amaçlandi.

Materyal ve Metot: Hastalar son 1 yıllık ortalama hemoglobinA1c (HBA1c) düzeylerine göre metabolik kontrol düzeyleri belirlendi. Ortalama HBA1c düzeyi <\% 7,5 iyi kontrol, $\% 7,6-9$ orta kontrol ve $>\% 9$ kötü kontrol olarak tanımlandı. Hasta verileri ile ortalama HBA1c düzeyleri karşılaştırıldı.

Bulgular: Toplam 144 hasta çalışmaya alındı. Pik tanı yaşı 4-6 yaş (\%21,51) ve $12-14$ yaş $(\% 20,83)$ olarak saptand. Hastaların \%10'unda birinci derece akrabalarında T1DM mevcuttu. Ortalama HBA1c düzeyleri kılarda $\% 7,7(7,2-8,8)$, erkeklerde $\% 7,8(7,0-8,6)$ idi. Hastaların \%38,19'i iyi, \%41,68'si orta ve \%20,13'si

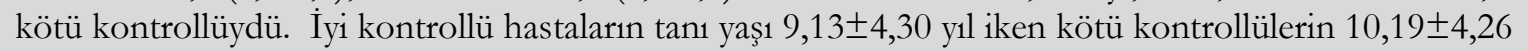
yıldı $(p=0,252)$. Çalışmada ailesinde T1DM mevcut olan grubun iyi metabolik kontrol düzeyine sahip olduğu görüldü $(\mathrm{p}=0,002)$.

Sonuç: Çalışmada ailesinde diyabet olanların daha iyi metabolik kontrole sahip olduğu saptandı. Bu durum hasta ve ailelerinin tanıdan sonra diyabet yönetimini önemsedikleri, yaşam tarzlarını diyabete uygun düzenledikleri düşündürmektedir. Bu sonuca göre aile içinde diyabet farkındalığının artırılması ve hastalara verilen eğitimlerin motive edici olması diyabet yönetiminde olumlu etki sağlayacaktır.

Anahtar kelimeler: Çocuk, Farkındalık, Metabolik kontrol, Tip 1 diabetes mellitus 
Effect of Baseline Clinical and Laboratory Characteristics of Patients with Type 1 Diabetes Mellitus on Metabolic Control

\author{
Yazışma Adresi / Correspondence: \\ Özlem Kara \\ e-mail: dr.ozlemkara@hotmail.com \\ Date of submission: 21.09.2019 \\ Date of admission: 15.11 .2019
}

\title{
Introduction
}

Type 1 diabetes mellitus is a chronic metabolic disease that is common in childhood, and which comprises destruction of pancreatic beta cells resulting in insulin deficiency. ${ }^{1}$ Diabetes, which was a fatal disease until the discovery of insulin, has become a chronic disease thereafter. This condition has revealed the complications of diabetes. Patients survive; however, this leads to severe burden on the patients, families and the health system due to long term complications. According to the Diabetes Control and Complications Trial (DCCT), a good metabolic control slows down and even prevents development of diabetes-related micro-vascular complications. ${ }^{2}$

Intensive insulin treatment is only one of the factors affecting glycemic control. However, many factors should be investigated regarding metabolic control of diabetes. Determination of the risk factors for poor metabolic control would significantly reduce the complications of diabetes. ${ }^{3}$

The duration of diabetes, glycemic control, genetic susceptibility, gender and environmental factors (smoking, alcohol, sedentary life style) increase the risk for vascular disease. ${ }^{4}$ Some studies have shown that demographic characteristics (such as age, gender) have an effect on HbA1c levels. ${ }^{5,6}$ Regular control, frequency of measuring plasma glucose, number of insulin injections and duration of diabetes are also associated with glycemic control., ${ }^{2,-9}$

Self-control of diabetes is usually implemented at home. Familial factors, economic status and psychological factors also affect glycemic control. ${ }^{10-12}$

The aim of this study was to determine the relationship between laboratory findings, demographic characteristics, presence of diabetes in the family and mean $\mathrm{HbA1c}$ level at the time of diagnosis of patients with type 1 diabetes.

\section{Materials and Methods}

\section{Patients}

A total of 144 patients, who had been diagnosed with T1DM aged 0.5 to 18 at Bursa Yuksek Ihtisas Research and Training Hospital between January 2015 and January 2018, whose data on admission could be reached and who had returned for regular outpatient clinic controls for at least one year were included in the study. Exclusion criteria were patients diagnosed with, or suspected of, non-T1DM (maturity onset diabetes of the young, neonatal diabetes, type 2 diabetes, secondary diabetes, etc.). The study protocol was approved by the Institutional Review Board of the hospital (2011-KAEK-25 2019/03-18) in accordance with the tenets of the declaration of Helsinki.

\section{General patient management}

Patients were diagnosed with T1DM according to the global IDF/ISPAD guideline. ${ }^{13}$ The date of the first insulin treatment was considered to be date of diagnosis. All patients were hospitalized on average 5 days for treatment and diabetes education. Patients were discharged with intensive insulin therapy. After discharge, self-blood glucose measurements continued at least 5 to 6 times/d: before meals, 2 hours after meals and at bedtime. Self-blood glucose measurements were evaluated fortnightly for the first 3 months and then every 3 months at outpatient clinic. In case of recurrent hypoglycemia, high HbA1c, hyperglycemia or ketoacidosis attacks, insulin dose change was performed. No serious hypoglycemic condition (seizure, coma, 
Effect of Baseline Clinical and Laboratory Characteristics of Patients with Type 1 Diabetes Mellitus on Metabolic Control

glucagon intervention) was detected in any patient's records. HbA1c values of patients were evaluated every three months. Hemoglobin A1c was measured using high-performance liquid chromatography (HPLC) technique (Adams Ha 8180v, BioDPC, USA).

\section{Data Collection}

The data collected were baseline data (including age, age at diabetes onset, diabetes, gender, family history of T1DM in first-degree relatives, the educational level of the family, season at the time of the diagnosis), laboratory data at onset (including plasma glucose, bicarbonate, $\mathrm{pH}$, insulin, HbA1c, c-peptide).

The mean annual HbA1c levels were calculated except for the levels at diagnosis. The metabolic control status was evaluated according to the mean HbA1c values of the previous year as good $(\mathrm{HbA} 1 \mathrm{c}<7.5 \%)$, moderate (HbA1c 7.5-9\%) and poor $(\mathrm{HbA} 1 \mathrm{c}>9 \%) .{ }^{14}$ The insulin dose of the patients at the last visit was calculated (units $/ \mathrm{kg} / \mathrm{d}$ ).

The patients were classified as hyperglycemia, ketosis and diabetic ketoacidosis (DKA) according to the laboratory findings at the time of admission. Hyperglycemia was defined as plasma glucose of $\geq 200 \mathrm{mg} / \mathrm{dl}$, together only with diabetes symptoms on admission or fasting plasma glucose $\geq$ $126 \mathrm{mg} / \mathrm{dl}$; ketosis was defined as ketonemia and hyperglycemia without acidosis, and DKA was defined as $\mathrm{pH}<7.30$ and $\mathrm{HCO} 3<15 \mathrm{mEq} / \mathrm{L}$ in addition to the above-mentioned criteria.

Diabetes auto-antibodies [glutamic acid decarboxylase autoantibodies (GADA), islet cell antibody (ICA), insulin autoantibody (IAA)], celiac auto-antibodies, thyroid function tests, anti-thyroid peroxidase, anti-thyroglobulin were evaluated retrospectively as the markers of auto-immunity.

Statistical analysis

The data was examined by the Shapiro Wilk test whether or not it presents normal distribution. Normally distributed data are presented as means with standard deviation and were compared with a two-sample t test and one-way ANOVA. Nonnormally distributed data are presented as medians with 25th and 75th percentiles and were compared using the Mann-Whitney $U$ and Kruskal Wallis tests. Bonferroni correction was performed for the multiple tests. Categorical variables were compared using Pearson's chi-squared and Yates's continuity correction. Correlations between variables were tested using Spearman correlation coefficient. $\mathrm{p}<0.05$ was considered as significance levels. Statistical analyses were performed with SPSS ver.17.0 (SPSS Inc. Released 2008. SPSS Statistics for Windows, Version 17.0. Chicago: SPSS Inc.). The patient data and the mean HbA1c levels were compared.

\section{Results}

A total of 144 T1DM patients (mean age of diagnosis $9.12 \pm 4.22$ years), of whom $71(49.30 \%)$ were girls (mean age of diagnosis $9.14 \pm 4.05$ years) and $73(50.70 \%$ ) were boys (mean age of diagnosis $9.09 \pm 4.41$ years), were included in the study. No difference was found between the gender with regard to age at diagnosis $(\mathrm{p}=0.887)$. The mean ages at diagnosis were determined to be $4-6$ years $(21.51 \%)$ and $12-14$ years $(20.83 \%)$. Most of the parents were graduates of elementary school. The first-degree relatives of $10.41 \%$ of the patients had T1DM (Table 1).

DKA was determined in $55.57 \%$ of the patients, hyperglycemia in $24.30 \%$ and ketosis was determined in $20.13 \%$ of the patients at the time of diagnosis. Most of the patients $(47.91 \%)$ had presented to the hospital in winter. Of the patients, $61.13 \%$ had GADA, 18.18\% had IAA, and $61.69 \%$ had ICA positivity. Thyroid antibodies were present in $11.11 \%$ of the patients and celiac antibodies were present in $1.38 \%$ of the patients (Table 2).

While the mean HbA1c level of all patients was 7.8\% (7.1-8.6), this value was 7.7\% (7.2-8.8) in girls and 7.8\% (7.0-8.6) in boys ( $\mathrm{p}=0.973)$. Metabolic control was good in $38.19 \%$ of the patients, moderate in $41.68 \%$ and poor in $20.13 \%$. While the age at diagnosis was $9.13 \pm 4.30$ years in 
Effect of Baseline Clinical and Laboratory Characteristics of Patients with Type 1 Diabetes Mellitus on Metabolic Control

patients with good metabolic control, it was $10.19 \pm 4.26$ years in patients with poor metabolic control $(\mathrm{p}=0.252)$. No difference was found between the metabolic control levels with regard to age at diagnosis. No difference was determined between metabolic control and gender, age at the time of admission, type of presentation, the season at the time of diagnosis, education level of the family and diabetes auto-antibody positivity. Metabolic control was found to be good in patients who had a family history of T1DM ( $\mathrm{p}=0.002)$ (Table 3). No difference was found between the metabolic control level and insulin, c-peptide, plasma glucose and the HbA1c levels on admission (Table 4).

Table 1. Demographic characteristics of cases at the time of diagnosis

\begin{tabular}{|l|c|}
\hline & $\mathbf{n}$ \\
\hline Gender* & $71(49.30)$ \\
$\quad$ Female & $73(50.70)$ \\
\hline Male & $9.10 \pm 4.22$ \\
\hline Age at diagnosis (mean year \pm sd) & $72(50.00)$ \\
Puberty at diagnosis* & $72(50.00)$ \\
$\quad$ Prepubertal & $15(10.41)$ \\
\hline First degree relatives with diabetes mellitus* & \\
\hline Mother education status* & $20(13.88)$ \\
Uneducated & $74(51.39)$ \\
Elementary school & $24(16.68)$ \\
Secondary school & $20(13.89)$ \\
College & $6(4.16)$ \\
High school & $10(6.94)$ \\
\hline Father education status* & $66(45.84)$ \\
Uneducated & $25(17.37)$ \\
Elementary school & $30(20.83)$ \\
Secondary school & $13(9.02)$ \\
College & $144(100)$ \\
High school & \\
\hline Total & \\
\hline
\end{tabular}

\section{Discussion}

The incidence of T1DM varies depending on age, gender, geographic region, family history and ethnicity. The incidence of the disease peaks at two ages, at preschool age (4-6 years) and early pubertal period (10-14 years). ${ }^{15}$ The peak age at the time of diagnosis was determined as 4-6 and 12-14, similar to the literature. Although auto-immune diseases are more frequent among girls, there is no difference between the genders for diabetes. ${ }^{16}$ However, it was found to be more frequent in some selected populations. ${ }^{17,18}$ Gender distribution was found to be similar in the present study. T1DM cases are commonly diagnosed in cold winters, similar to that found in the present study. This result supports the hypothesis that viral infections, which increase in these seasons, lead to beta cell destruction through cross-reaction. ${ }^{19}$

Familial inheritance is seen in about $10 \%$ of T1DM cases in many studies. ${ }^{20,21}$ A family history of diabetes was detected at a similar rate in the present study.

Metabolic control is affected by many factors in T1DM., ${ }^{2,-9}$ In particular, the frequency of longterm vascular complications varies depending on the metabolic control level. Unfortunately, diabetes complications continue to be the causes of morbidity and mortality. ${ }^{4}$ 
Effect of Baseline Clinical and Laboratory Characteristics of Patients with Type 1 Diabetes Mellitus on Metabolic Control

Table 2. Clinical and laboratory characteristics of the patient's time of diagnosis

\begin{tabular}{|c|l|}
\hline & $\mathrm{n}(\%)$ \\
\hline Diagnosis type & $35(24.30)$ \\
Hyperglycemia & $29(20.13)$ \\
Ketosis & $80(55.57)$ \\
Ketoacidosis & \\
Season of diagnosis & $32(22.22)$ \\
Spring & $16(11.12)$ \\
Summer & $27(18.75)$ \\
Autumn & $69(47.91)$ \\
Winter & \\
Metabolic control & $55(38.19)$ \\
Good & $60(41.68)$ \\
Moderate & $29(20.13)$ \\
Poor & \\
GADA & $88(61.13)$ \\
ICA & $89(61.69)$ \\
IAA & $26(18.18)$ \\
\hline Autoantibody positivity & $16(11.11)$ \\
\hline The presence of thyroid antibodies & $2(1.38)$ \\
\hline
\end{tabular}

(GADA, glutamic acid decarboxylase autoantibodies; ICA, islet cell autoantibody; IAA, insulin autoantibody)

In the study, metabolic control was poor in $20.13 \%$ of the patients. The rate of poor metabolic control had been determined as $50 \%$ in a study from Turkey. ${ }^{22}$ Metabolic control is affected by close plasma glucose follow-up, healthy nutrition, sufficient insulin treatment and exercise levels, despite variation between centers.

In the present study, while the mean age at the time of diagnosis was $9.13 \pm .4 .30$ years in patients with good metabolic control, it was $10.19 \pm 4.26$ years in patients with poor metabolic control; however, no significant difference was found between age at the time of diagnosis and metabolic control $(p=0.252)$. Metabolic control was determined to be poorer in the 14-18-year age group compared to the 2-8 years age group; however, the mean HbA1c levels were found to be higher in the younger age group in the study of Shalitin et al. ${ }^{3,23}$ No association was determined between age and metabolic control in the study conducted by Dorchy et al. ${ }^{24}$

Of the patients, $55.57 \%$ had presented with DKA in the present study. This rate varies between $30-50 \%$ in various studies. ${ }^{25}$ Younger age, ethnic minority and absence of health insurance were determined as significant factors that increase the DKA frequency in a systematic review, which included more than 24000 children from 31 countries worldwide. ${ }^{26}$

No association was found between the type of presentation and metabolic control. However, some studies have revealed that metabolic control is poor in patients presenting with DKA. ${ }^{27}$

The patients whose family members had a history of diabetes were determined to present with DKA at a lower rate. This was associated with increased awareness. Metabolic control was also found to be more favorable in patients who had a family history of diabetes. Fredheim et al. determined that the presence of diabetes in the family reduced the rate of admission with DKA; however, the HbA1c levels were found to be higher in the long-term follow-up of these patients. ${ }^{28}$ 
Effect of Baseline Clinical and Laboratory Characteristics of Patients with Type 1 Diabetes Mellitus on Metabolic Control

Table 3. Evaluation of the clinical and laboratory features of the cases according to the control level

\begin{tabular}{|c|c|c|c|c|}
\hline & $\begin{array}{l}\text { Good } \\
\text { control } \\
\text { n:55 } \\
(38.19 \%)\end{array}$ & $\begin{array}{l}\text { Moderate } \\
\text { control } \\
\text { n:60 } \\
(41.68 \%)\end{array}$ & $\begin{array}{l}\text { Poor } \\
\text { control } \\
\text { n:29 } \\
(20.13 \%)\end{array}$ & $\mathrm{p}$ \\
\hline \multicolumn{5}{|l|}{$\begin{array}{l}\text { Gender }^{*} \\
0.571^{\S}\end{array}$} \\
\hline Female & $27(38.02)$ & $32(45.07)$ & $12(16.91)$ & \\
\hline Male & $28(38.37)$ & $28(38.35)$ & $17(23.28)$ & \\
\hline \multicolumn{5}{|l|}{$\begin{array}{l}\text { Puberty }^{*} \\
0.477^{\S}\end{array}$} \\
\hline Prepubertal & $27(37.50)$ & $33(45.83)$ & $12(16.67)$ & \\
\hline Pubertal & $28(38.89)$ & $27(37.50)$ & $17(23.61)$ & \\
\hline Age at diagnosis (mean year \pm sd) & $9.13 \pm 4.30$ & $8.60 \pm 4.10$ & $10.19 \pm 4.26$ & $0.252^{\dagger}$ \\
\hline \multicolumn{5}{|l|}{$\begin{array}{l}\text { Season of diagnosis } \\
0.895^{*}\end{array}$} \\
\hline Spring & $10(31.25)$ & $16(50)$ & $6(18.75)$ & \\
\hline Summer & $7(43.75)$ & $6(37.50)$ & $3(18.75)$ & \\
\hline Autumn & $11(40.74)$ & $12(44.44)$ & $4(14.81)$ & \\
\hline Winter & $27(39.14)$ & $26(37.68)$ & $16(23.18)$ & \\
\hline \multicolumn{5}{|l|}{$\begin{array}{l}\text { Diagnosis type } \\
0.621^{*}\end{array}$} \\
\hline Hyperglycemia & $12(34.28)$ & $13(37.15)$ & $10(28.57)$ & \\
\hline Ketosis & $13(44.82)$ & $12(41.37)$ & $4(13.79)$ & \\
\hline Ketoacidosis & $30(37.50)$ & $35(43.75)$ & $15(18.75)$ & \\
\hline \multicolumn{5}{|l|}{ Autoantibody positivity $^{*}$} \\
\hline GADA & $35(39.77)$ & $36(40.90)$ & $17(19.33)$ & $0.881^{\S}$ \\
\hline ICA & $36(40.46)$ & $38(42.69)$ & $15(16.85)$ & $0.445^{\S}$ \\
\hline IAA & $11(42.31)$ & $11(42.31)$ & $4(15.38)$ & $0.779^{\S}$ \\
\hline $\begin{array}{l}\text { The presence of thyroid } \\
\text { antibodies }\end{array}$ & $8(50.00)$ & $5(31.25)$ & $3(18.75)$ & $0.541^{\S}$ \\
\hline The presence of celiac antibodies ${ }^{*}$ & - & $2(100)$ & - & $0.246^{\S}$ \\
\hline First degree relatives with T1DM ${ }^{*}$ & $12(80.00)$ & $3(20.00)$ & - & $0.002^{\S}$ \\
\hline
\end{tabular}

GADA, glutamic acid decarboxylase autoantibodies; ICA, islet cell autoantibody; IAA, insulin autoantibody; T1DM, Type 1 diabetes mellitus

${ }^{*} \mathrm{n}(\%) \Im$ Chi-square test, parameters are shown as $\mathrm{n}(\%) \dagger$ One-Way ANOVA test, parameters are shown as mean \pm sd $\ddagger$ Kruskal Wallis test, parameters shown as median (25-75th percentile)

Table 4. Evaluation of laboratory features of the patients according to the control level

\begin{tabular}{|l|l|l|l|l|}
\hline & $\begin{array}{l}\text { Good control } \\
\mathbf{n}: 55 \mathbf{3 8 . 1 9 \%})\end{array}$ & $\begin{array}{l}\text { Moderate control } \\
\mathbf{n : 6 0 ( 4 1 . 6 8 \% )}\end{array}$ & $\begin{array}{l}\text { Poor control } \\
\mathbf{n}: \mathbf{2 9}(\mathbf{2 0 . 1 3} \mathbf{0})\end{array}$ & $\mathbf{p}$ \\
\hline Glucose $(\mathrm{mg} / \mathrm{dl})$ & $472 \pm 172$ & $494 \pm 172$ & $479 \pm 194$ & $0.798^{\S}$ \\
\hline Insuline $(\mu \mathrm{U} / \mathrm{ml})$ & $2(1-4)$ & $2(1.1-3.7)$ & $2(1-3.2)$ & $0.832^{\dagger}$ \\
\hline $\begin{array}{l}\text { c-peptite } \\
(\mathrm{ng} / \mathrm{ml})\end{array}$ & $0.30(0.18-0.55)$ & $0.27(0.2-0.5)$ & $0.36(0.2-0.55)$ & $0.444^{\dagger}$ \\
\hline $\mathrm{HbA1}(\%)$ & $12.1 \pm 2.31$ & $11.7 \pm 2.0$ & $12.4 \pm 2.07$ & $0.361^{\S}$ \\
\hline $\mathrm{pH}$ & $7.25(7.13-7.37)$ & $7.26(7.12-7.34)$ & $7.28(7.19-7.36)$ & $0.478^{\dagger}$ \\
\hline $\mathrm{HCO} 3(\mathrm{mEq} / \mathrm{L})$ & $14.9(9.3-21)$ & $14.8(7.1-18.2)$ & $16.6(11.6-19.2)$ & $0.362^{\dagger}$ \\
\hline
\end{tabular}

S One-Way ANOVA test, parameters are shown as mean \pm sd $\dagger$ Kruskal Wallis test, parameters shown as median (25-75th percentile) 
In conclusion, it has been observed that patients who have T1DM in family have good metabolic control. Cooperation with the patient and their family is very important in diabetes management. Increasing awareness of family members with type 1 diabetes about diabetes has a positive effect on diabetes management.

Conflicts of interest: There are no conflicts of interest

\section{References}

1. Atkinson MA, Eisenbarth GS. Type 1 diabetes: new perspectives on disease pathogenesis and treatment. Lancet 2001;358(9277):221-9.

2. Diabetes Control and Complicatons Trial Research Group. The effect of intensive treatment of diabetes on the development and progression of long-term complications in insulin-dependent diabetes mellitus. N Engl J Med 1993:329(14):977-86.

3. Urbach SL, LaFranchi S, Lambert L, Lapidus JA, Daneman D, Becker TM. Predictors of glucose control in children and adolescents with type 1 diabetes mellitus. Pediatric Diabetes 2005;6:69-74.

4. Maahs DM, West NA, Lawrence JM, Mayer-Davis EJ. Epidemiology of type 1 diabetes. Endocrinol Metab Clin North Am 2010;39(3):481-97.

5. Daneman D, Wolfson DH, Becker DJ, Drash AL. Factors affecting glycosylated hemoglobin values in children with insulin-dependent diabetes. J Pediatr 1981;99(6):847-53.

6. Mortensen HB, Robertson KJ, Aanstoot HJ et al. Insulin management and metabolic control of type 1 diabetes mellitus in childhood and adolescence in 18 countries. Diabet Med 1998;15:752-9.

7. Jacobson AM, Hauser ST, Willett J, Wolfsdorf JI, Herman L. Consequences of irregular versus continuous medical follow-up in children and adolescents with insulin-dependent diabetes mellitus. J Pediatr 1997;131(5):727-33.

8. Levine BS, Anderson BJ, Butler DA, Antisde JE, Brackett J, Laffel LM. Predictors of glycemic control and short-term adverse outcomes in youth with type 1 diabetes. J Pediatr. 2001;139(2):197-203.

9. Rosilio M, Cotton J-B, Wieliczko M-C et al. Factors associated with glycemic control. A crosssectional nationwide study in 2,579 French children with type 1 diabetes. The French Pediatric Diabetes Group. Diabetes Care 1998;21(7):1146-53.

10. Kaufman FR, Halvorson M, Carpenter S. Association between diabetes control and visits to a multidisciplinary pediatric diabetes clinic. Pediatrics 1999;103:948-51.

11. Rovet JF, Ehrlich RM. Effect of temperament on metabolic control in children with diabetes mellitus. Diabetes Care 1988;11:77-82.

12. Songer TJ, Laporte RE, Lave JR, Dorman JS, Becker DJ. Health insurance and the financial impact of IDDM in families with a child with IDDM. Diabetes Care 1997:20 (4):577-84.

13. Craig ME, Hattersley A, Donaghue K. Definition, epidemiology and classification in Global IDF/ISPAD Guideline for Diabetes in Childhood and Adolescence, R. Hanas, et al., Editors. 2011:8-16.

14. Rewers M, Pihoker C, Donaghue K, Hanas R, Swift P, Klingensmith GJ. Assesment and monitoring of glycemic control, in Global IDF/ISPAD Guideline for Diabetes in Childhood and Adolescence, R. Hanas, et al., Editors. 2011:50-9.

15. Soltesz G. Diabetes in the young: A paediatric and epidemiological perspective. Diabetologia 2003;46:447-54.

16. Dabelea D, Mayer-Davis EJ, Saydah, et al. Prevalence of type 1 and type 2 diabetes among children and adolescents from 2001 to 2009. Jama, 2014;311(17):1778-86.

17. Gale EA, Gillespie KM. Diabetes and gender. Diabetologia. 2001;44(1):3-15.

18. Quinn M, Fleischman A, Rosner B, et al. Characteristics at diagnosis of type 1 diabetes in children younger than 6 years. J Pediatr. 2006;148(3):366-71.

19. Moltchanova EV, Schreier N, Lammi N, Karvonen M. Seasonal variation of diagnosis of Type 1 diabetes mellitus in children worldwide. Diabet Med. 2009;26(7):673-8.

20. Demirbilek H, Özbek MN, Baran RT. Incidence of type 1 diabetes mellitus in Turkish children from the Southeastern region of the country: A regional report. J Clin Res Pediatr Endocrinol 2013;5:98-103. 
Effect of Baseline Clinical and Laboratory Characteristics of Patients with Type 1 Diabetes Mellitus on Metabolic Control

21. Kandemir N, Açıkgöz E, Yordam N. The epidemiology of juvenile onset insuline-dependent diabetes mellitus in Turkish children. A retrospective analysis of 477 cases. Turk J Pediatr 1994;36(3):191-5.

22. Kocabaş A, Kocabaş AB, Karagüzel G, Akçurin S. Tip 1 diyabetes mellitus olgularımızın antropometrik ve metabolik izlem özelliklerinin değerlendirilmesi. Turkish Journal of Pediatric Disease2013;3:113-8.

23. Shalitin S, Fisher S, Yackbovitch-Gavan M, et al. Ketoacidosis at onset of type 1 diabetes is a predictor of long-term glycemic control. Pediatr Diabetes. 2018;19(2):320-8.

24. Dorchy H, Roggemans MP, Willems D. Glycated hemoglobin andrelatedfactors in diabetic children and adolescents under 18 years of age: a Belgian experience. Diabetes Care 1997;20(1):26.

25. Dabelea D, Rewers A, Stafford JM, et al. Trends in the prevalence of ketoacidosis at diabetes diagnosis: the SEARCH for diabetes in youth study. Pediatrics. 2014;133(4):e938-e945.

26. Usher-Smith JA, Thompson MJ, Sharp SJ, Walter FM. Factors associated with the presence of diabetic ketoacidosis at diagnosis of diabetes in children and young adults: a systematic review. BMJ 2011;343:d4092.

27. Pinkey JH, Bingley PJ, Sawtell PA, Dunger DB, Gale EA. Presentation and progress of childhood diabetes mellitus: a prospective population-based study. The Bart's-Oxford Study Group. Diabetologia 1994;37(1):70-4.

28. Fredheim S, Johannesen J, Johansen A, et al. Diabetic ketoacidosis at the onset of type 1 diabetes is associated with future HbA1c levels. Diabetologia 2013;56:995-1003. 